Filol. linguíst. port., São Paulo, 15(2), p. 565-594, Jan./Jun. 2013.

DOI: http://dx.doi.org/10.11606/issn.2176-9419.v15i2p565-594.

\title{
A Responsividade do leitor no gênero "Carta do Leitor" na mídia impressa de referência: Análise de polêmicas discursivas na perspectiva bakhtiniana
}

Reader answerability in the genre "Readers Letters "in the press: analysis of discursive polemics from a Bakhtinian perspective

\author{
Simone Ribeiro de Avila Veloso \\ Universidade Estadual Paulista, Brasil \\ simoneribeirovls@gmail.com
}

Resumo: O presente artigo tem como objetivo expor parte de uma pesquisa, desenvolvida em nível de pós-doutorado, cujo propósito é investigar a responsividade do leitor no gênero "carta do leitor" em enunciados concretos publicados pelos jornais Folha de S. Paulo, O Estado de S. Paulo e revista Veja. O estudo considera, especificamente, os discursos refratados, sinalizados por meio das polêmicas aberta e velada, entabulados pelos leitores de cada um dos veículos de comunicação, a partir da arquitetônica constitutiva dos enunciados concretos. O enfoque analítico se centralizará no modo como os leitores polemizam os discursos representativos das esferas políticas instituídas, observando-se um contexto de transição política caracterizado pelo último governo militar. Para tanto, foram selecionadas cartas publicadas, concomitantemente, nos três veículos, na primeira quinzena de fevereiro de 1980, uma vez que o presente artigo observa os eventos que ganharam repercussão nas três empresas constitutivas da mídia impressa de referência.

Palavras-chave: Gêneros do discurso; Cartas do leitor; Polêmicas discursivas

Abstract: This paper aims to present part of a research, developed at a post-doctoral level, whose purpose is to investigate the answerability of the reader in the genre "readers letters" in 
concrete utterances published in the newspapers Folha de S. Paulo and O Estado de S. Paulo and Veja magazine. The study considers specifically the refracted speeches marked by open and veiled polemics, achieved by the readers of each of the media, in view of the architectonics constitutive of concrete utterances. The analytical focus will center on how readers polemize with speeches representative of the established political spheres, observing a context of political transition characterized by the last military government. With this end in view, we selected letters published, concurrently in those three vehicles in the first half of February 1980, in order to observe the events that were reported in the three media corporations.

Keywords: speech genres, readers letters; discursive controversies

\section{INTRODUÇÃ̃}

Este artigo se constitui um recorte de uma pesquisa desenvolvida em nível de pós-doutoramento que focaliza os modos de refração discursiva configurados pelas polêmicas aberta e velada ${ }^{1}$, compreendidas como expressões do discurso bivocal (BAKHTIN, 2008 [1963])² . O objetivo é considerar a responsividade do leitor no gênero discursivo "carta do leitor" em enunciados concretos publicados nos jornais Folha de S. Paulo e O Estado de S. Paulo, bem como na revista Veja.

A pesquisa, como um todo, seleciona cartas considerando-se a repercussão de eventos tanto da esfera política, quanto da esfera da ideologia do cotidiano, nos três veículos de comunicação, em publicações realizadas no período compreendido entre 1980 e 2010, observando-se acontecimentos sócio-históricos que marcaram o recente contexto político brasileiro, começando pelo período de transição política, evidenciado pelo último governo militar.

É com esse propósito que destacaremos as análises das missivas publicadas na primeira quinzena de fevereiro de 1980, momento caracterizado pelo início

\footnotetext{
${ }^{1}$ Em pesquisa anterior (VELOSO, 2011), desenvolvemos estudo sobre as polêmicas aberta e velada em análises de entrevistas televisivas com cientistas e acadêmicos.

${ }^{2} \mathrm{~A}$ primeira data refere-se à $4^{\mathrm{O}}$ edição de Problemas da poética de Dostoiévski, traduzida por Paulo Bezerra. Entre colchetes, foi destacada a data de publicação da primeira edição da obra.
} 
do governo do General Figueiredo. Tais análises levam em consideração pressupostos teóricos referentes à noção de gênero do discurso presente em Medviédev (2012 [1928]) e Bakhtin (2006 [1952-53]), dentre outras obras do chamado Círculo de Bakhtin. Também serão observadas as noções de arquitetônica e responsividade delineadas principalmente em Bakhtin (2010 [1920-24]) e de discurso bivocal evidenciados em Bakhtin (2008[1963]) e Bakhtin (2002 [1934-35]); bem como de enunciado concreto proposta por Volochínov (1981 [1926]) e Volochínov (1981 [1930]).

A investigação sinaliza três diferentes modos de responsividade do leitor delineados em três diferentes contextos de interlocução, uma vez que forjados por diferentes projetos discursivos de cada um dos enunciadores - Folha de São Paulo, O Estado de S. Paulo e Veja - que compõem parte das mídias impressas de referência.

\section{O APORTE TEÓRICO BAKHTINIANO PARA ANÁLISE DE POLÊMICAS DISCURSIVAS}

Já no final dos anos de 1970, o contexto político brasileiro seria caracterizado pela alternância entre ações de repressão política e sinais de abertura democrática, ambos patrocinados pelo poder público instituído. Carvalho (2008) explicita um cenário conjuntural evidenciado pelas consequências da crise do preço do petróleo, o que provocaria relativa desestabilização econômica e, consequentemente, fragilização das bases econômicas que fundamentavam o regime político de exceção. Vale a pena ainda ressaltar a crescente urbanização de regiões como São Paulo que, por meio, por exemplo, da instalação de novas indústrias automobilísticas, fomentou a emergência de classes organizadas de trabalhadores. Tal horizonte social amplo delineia-se constitutivo das cartas dos leitores publicadas pelos jornais Folha de S. Paulo e O Estado de S. Paulo, assim como pela revista Veja.

Considerando-se a perspectiva teórico-metodológica bakhtiniana, a análise do enunciado concreto, compreendido como unidade real da comunicação discursiva (BAKHTIN, 2006 [1952-53]: 269) mobiliza, além do estudo do referido contexto como elemento imprescindível para a constituição do sentido, o foco na arquitetônica desse enunciado. Em O problema do conteúdo, do material e da forma na criação literária, texto ainda publicado na década de 1920, Bakhtin (2002 [1924]) evidencia a arquitetônica como forma de acabamento que propicia formas composicionais específicas. Dessa forma, a tragédia, por exemplo, constitui-se como arquitetônica do drama, enquanto forma composicional em atos; o humor suscitaria o acabamento para composições (gêneros discursivos) como novelas, contos, poemas, etc. Posteriormente, o autor afirma: 
As formas arquitetônicas são as formas dos valores morais e físicos do homem estético, as formas da natureza enquanto seu ambiente, as formas do acontecimento no seu aspecto de vida particular, social, histórica (...) são as formas da existência estética na sua singularidade (...). (BAKHTIN, 2002 [1924]: 25)

Compreende-se, destarte, que a noção de arquitetônica vincula-se à ideia de acabamento, definido a partir do projeto discursivo do sujeito, imbuído de valores éticos e cognitivos, uma vez que as concepções de "tragédia" e "humor", por exemplo, configuram-se elementos culturais historicamente definidos. Nesse sentido, a "singularidade" deve ser entendida tendo em vista aspectos sóciohistóricos que determinam a produção, circulação e recepção de um enunciado. Desse modo, os gêneros discursivos delineiam-se tendo em vista tal projeto configurado na inter-relação entre a singularidade do evento e os valores culturais mais amplos constitutivos de determinada sociedade.

Partindo do pressuposto de que tais valores nem sempre se apresentam de modo convergente entre os sujeitos que exercem papéis sociais, destacamos as polêmicas discursivas enquanto tipo de discurso em que há um embate entre vozes sociais. A esse propósito, Bakhtin (2008 [1963]) observa a existência de relações dialógicas, entendidas como de natureza extralinguística, e que podem se configurar convergentes ou divergentes, em situações reais de interlocução. No momento em que o discurso do autor/ sujeito se orienta para análise do objeto de sentido/tema, é possível que, subjacente a tal fala, se circunscreva uma resposta/reação contrária ao discurso do outro, que se mantém fora dos limites do discurso do autor. Trata-se da polêmica velada, em que o embate discursivo se delineia por meio da análise de um tema, entendido em sua singularidade. Tal fenômeno discursivo pode ser percebido no uso da ironia, palavras que resguardam duplo sentido, etc.

Por outro lado, quando a fala do outro aparece claramente como foco de contraposição, sendo mobilizada por meio de discurso direto ou pela nomeação em que há a explicitação de um juízo de valor, emerge, nesse caso, o fenômeno da polêmica aberta (BAKHTIN, 2008 [1963]: 224).

O presente artigo considera os dois tipos de polêmicas constitutivas das cartas dos leitores dos três veículos de comunicação já citados. Vale pontuar que o mídium ${ }^{3}$ deve ser focalizado como elemento constitutivo das

\footnotetext{
${ }^{3}$ Compreende-se "midium" como suporte, meio material pelo qual circulam os discursos. De acordo com Maingueneau (2002), a escolha de um determinado mídium configura-se fundamental na formulação do próprio gênero do discurso (MAINGUENEAU, 2002: 72). De uma perspectiva bakhtiniana, compreendese o suporte em estreita interação com o aspecto institucional que integra a constituição do sujeito enunciador representado por cada um dos veículos de comunicação (FSP, OESP e Veja).
} 
relações dialógicas entabuladas entre os discursos dos sujeitos envolvidos: leitores/autores, demais leitores, enunciador/jornalista, autoridades políticas. Tal fato se justifica na medida em que cada empresa jornalística apresenta um histórico de constituição que lhes confere um teor de credibilidade junto aos seus públicos leitores, o que determina modos peculiares de recepção dos textos.

Partindo de tais considerações, duas perguntas devem orientar as análises: 1) de que modo os leitores de cada veículo de comunicação (FSP, OESP e Veja) instauram polêmicas contra os discursos oriundos das esferas públicas instituídas?; 2) de que forma temas da ideologia do cotidiano, compreendida como "totalidade da atividade mental centrada sobre a vida cotidiana" (VOLOCHÍNOV/BAKHTIN, 2004[ 1929]: 118), apresentam-se refratados (polemizados) em tais cartas?

\section{TRÊS PERSPECTIVAS IDEOLÓGICAS DISTINTAS EM TRÊS DIFERENTES VEÍCULOS DE COMUNICAÇÃO}

Considerando a primeira quinzena de fevereiro de 1980, início do primeiro ano de governo do General Figueiredo, foram selecionadas cartas a partir de dois critérios: 1) repercussão de eventos nos três veículos, a partir de um levantamento da recorrência temática; 2) constituição de um corpus representativo que evidencie: (i) discursos refratados manifestos pelas polêmicas aberta e velada e (ii) discursos refletidos, explicitados por meio de cartas elogiosas, propositivas e de solicitação.

Realizada a composição do corpus representativo, serão focalizadas as seguintes categorias discursivas de análise:

I. Discursos refratados: representados pelas polêmicas aberta e velada, de modo a viabilizar a observação de: (a) polêmicas instauradas pelos leitores contra discursos das autoridades públicas instituídas; (b) polêmicas instauradas pelos leitores no tratamento de temas que circulam na esfera da ideologia do cotidiano, considerando-se os níveis elevados (discursos representativos de lideranças constituídas de classe) e niveis inferiores (explicitam usos e costumes populares).

II. Discursos refletidos: representados por discursos elogiosos, propositivos e de solicitação.

Observemos, nas próximas subseções, as análises de enunciados dos três veículos. Em seguida, delinearemos um estudo comparativo dos resultados. 


\subsection{OS DISCURSOS INSCRITOS EM A PALAVRA DO LEITOR, $D A F S P$}

Antes de observarmos quais discursos emergem de tais cartas e, consequentemente, quais temas configuram-se recorrentes, é preciso situar o espaço reservado a essas missivas ${ }^{4}$ : delimitadas a uma coluna estreita do lado direito da seção intitulada "Tendências e Debates", em que são contrapostas opiniões de conceituados intelectuais, especialistas, jornalistas, acerca de temas que ganharam repercussão na mídia e em demais esferas da sociedade, tais cartas aparecem impreterivelmente na página 02 de cada edição, fato que já lhes confere um duplo caráter: de um lado, são compreendidos como "textos de opinião", tendo em vista o lugar de publicação legitimado em que se circunscrevem diversos pontos de vistas; de outro, entabula diálogo com outros discursos que circularam, eventualmente, em outros enunciados de outros gêneros do jornal ou até mesmo entre enunciados do próprio gênero carta do leitor.

O segundo aspecto que merece destaque é o título da coluna "A Palavra do Leitor", em que, a despeito do uso de letras maiúsculas que atribuem efeito de importância à figura do interlocutor do jornal (leitor), também demarcam espaços de vozes que circulam no jornal: é como se o veículo dissesse "nesse espaço não somos nós que falamos, e sim o leitor". A delimitação de vozes é reiterada, inclusive, no uso de aspas que precede o início de cada parágrafo das cartas. Há, portanto, subjacente a esse "singelo" movimento um viés ideológico instalado: primeiro, constituir-se um jornal que oferece espaço de fala aos seus leitores (mesmo que em uma estreita coluna da página 2); segundo, o esforço de não se comprometer com as opiniões que circulam nesses enunciados, pressupondo, eventualmente, a pluralidade de outras opiniões existente entre leitores do referido jornal.

Um terceiro elemento constitutivo da forma composicional de tais enunciados é a presença de títulos que sinalizam a temática abordada. Cada título pode contemplar mais de uma carta, por vezes até polêmicas entre si ao tomar, quer seja o mesmo conteúdo objetal como foco de avaliação (polêmica velada), quer seja o discurso do outro como base de contraposição (polêmica aberta).

Por último, há ainda que se considerar a forma de identificação do leitor, tratado sempre por Sr., Sra. ou pela profissão: Eng. Agro., médico (nesse caso Dr.), etc. Os nomes, ora aparecem abreviados, ora parcialmente registrados pelo sobrenome, ora com os nomes por extenso, seguido do lugar de origem: Capital, SP; Taubaté, SP, etc., informações que conferem autoria a tais enunciados. É por meio dessa autoria que se estabelece o tratamento axiológico dos temas levantados. A imagem 
A Responsividade do leitor no gênero...

Reader answerability in the genre...

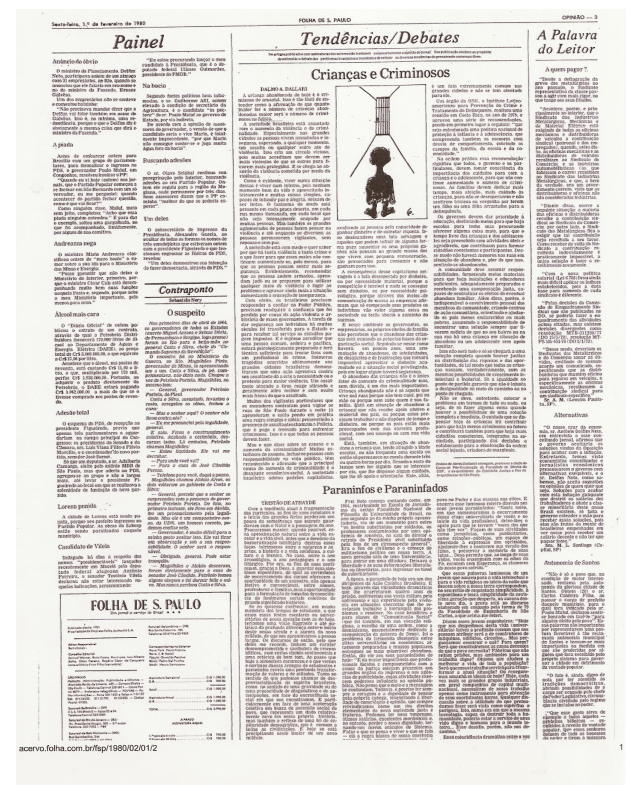

Figura 1: Página 2 da edição da FSP de 01/02/1980

seguinte apresenta a página 2 da edição da FSP de 01/02/1980, disponível no link http:://acervo.folha.com.br/fsp/1980/02/01/2:

$\mathrm{Na}$ sequência, mobilizamos as seguintes categorias discursivas a partir da análise da recorrência temática, de modo a evidenciar três tendências axiológicas constitutivas da responsividade do leitor: 1) discursos refratados em que são instauradas polêmicas contra discursos articulados em esferas do poder público politico instituído;2) discursos refratados entre discursos que circulam na esfera da ideologia do cotidiano, considerando níveis superiores e inferiores; e 3) discursos refletidos, em que se apresentam cartas elogiosas; cartas propositivas em que o leitor apresenta sugestões, propostas; e, finalmente, cartas de solicitação, em que o leitor solicita uma retificação de informação ao jornal.

\footnotetext{
${ }^{4}$ Ressalta-se que o período mencionado refere-se à primeira quinzena de fevereiro de 1980 .
} 
Com vistas à realização de um levantamento quantitativo, foram consultadas 15 edições, contendo entre 3 e 5 cartas cada uma delas ${ }^{5}$ :

\section{Discursos refratados}

\section{I.I Interface entre a ideologia do cotidiano e esferas instituídas.}

- Polêmicas contra discursos das autoridades políticas instituídas (16).

- Polêmicas contra discursos advindos da esfera político-econômica (01).

- Polêmicas contra discursos oficiais oriundos da esfera da educação (05).

- Polêmicas contra discursos da esfera da religião (04).

- Polêmicas contra discursos da esfera midiática (02).

\section{Subtotal: 28}

I.II Interface entre discursos que circulam na esfera da ideologia do cotidiano: níveis superiores e inferiores

Níveis superiores

- Expressão axiológica de indignação: incitação ao engajamento político (02).

- Expressão axiológica de indignação: cobrança institucional indevida de taxas e multas, preço alto, demora na restituição do imposto de renda, repasse reduzido de verbas $(05)$.

- Polêmica contra dirigentes esportivos e/ou imprensa (03).

- Polêmica contra discursos de técnicos agrícolas (01).

\footnotetext{
${ }^{5}$ A seção de cartas do leitor no jornal FSP aparece inicialmente em 14 de agosto de 1963, segundo arquivo disponível em < acervo.folha.com.br/fsp > .Intitulava-se "Cartas à Redação" e a fala do leitor constituía-se de modo indireto, evidenciando o trabalho do editor do jornal. Até 1976, a referida coluna sofre algumas alterações, passando a denominar-se "O Povo Reclama". Chega a desaparecer em breves momentos, como em 07 de dezembro de 1966 em que, no espaço correspondente às cartas, o jornal publicou a seguinte mensagem: "Critique menos e trabalhe mais. O país é seu. Confiamos no Brasil. Campanha da Folha de S. Paulo". A partir de 1976, recebe o nome de "A palavra do leitor". Após 1986, já em plena República Nova, apresenta-se como "Painel do Leitor", o que perdura atualmente.
} 
A Responsividade do leitor no gênero...

\section{Subtotal: 11}

\section{Niveis inferiores}

- Costumes/comportamento: uso do topless, "cornetões" nos estádios, filas (10).

- Violência urbana (apenas um caso e, mesmo assim, reflete posicionamento de defesa ao criminoso)(01).

- Retirada dos nomes das listas telefônicas (01).

\section{Subtotal: 12}

\section{Total: 51}

\section{Discursos refletidos}

\section{II.I Cartas elogiosas}

- Expressão axiológica de elogio a discursos de entidades femininas de defesa dos direitos das prostitutas (01).

- Discurso elogioso à FSP por publicar entrevista com representante da Associação Profissional das Empregadas Domésticas. (01)

- Discurso elogioso à FSP pela obtenção de financiamento junto ao Banco do Brasil, após publicação de carta em edição anterior (01).

\section{II.II Cartas propositivas}

- Incentivo à pesca (01).

- Não suspensão de atividades de consórcio (1).

\section{II.III Cartas de solicitação}

- Solicita retificação de informação publicada incorretamente (01).

- Pedido ao governador de São Paulo para não instalar presídio em Ubatuba (04). 


\section{Total: 10}

Considerando-se o contexto de publicação de tais enunciados concretos, Chaparro (1987) destaca que a carta, enquanto prática jornalística, constitui-se "concessão ao leitor, administrada em proveito do jornal, em cujas mensagens o leitor só acidentalmente interfere" (CHAPARRO, 1987: 63). Nesse estudo, o autor focaliza as cartas dos leitores no âmbito do chamado "Projeto Editorial da Folha" que determinaria, por meio do Manual do jornal, "a publicação ou responsabilização de toda carta enviada à redação" (CHAPARRO, 1987: 67). Contudo, vale destacar que nem toda correspondência enviada à editoria responsável é publicada. Corrêa (2008), em estudos realizados no escopo teórico da sócio-retórica, observa o papel do editor tanto no processo de seleção quanto de edição das cartas. Dessa forma, compreende-se que as publicações resultam de um trabalho intencional por parte do enunciador (FSP).

No que tange às análises das cartas dos leitores, é preciso ressaltar que o presente estudo não tem por objetivo enveredar por critérios quantitativos, contudo, vale a pena considerar que nas 61 cartas publicadas no período (primeira quinzena de fevereiro de 1980) há claramente o predomínio de discursos refratados, ou seja, que entabulam polêmicas contra outros discursos - e isso ocorre em 51 delas. Dois temas se sobressaem: o primeiro que articula saberes da esfera política com a da ideologia do cotidiano, em que são refratados discursos que representam as autoridades políticas instituídas e, em seguida, aparecem temas que circulam nos níveis inferiores da ideologia do cotidiano, em especial o uso de topless.

A título de uma análise qualitativa, consideremos, abaixo, quatro cartas representativas respectivamente desses dois conjuntos temáticos:

\section{$1^{\text {o }}$ conjunto temático: Polêmicas contra discursos das autoridades políticas instituídas}

\section{Cartas}

Peculiar concepção

"Em pelo menos três ocasiões o presidente João Batista Figueiredo deixou no ar uma peculiar concepção de democracia e de postura democrática. Depois de jurar 'fazer deste País uma democracia', no seu discurso de posse, S. Exa. nos advertiu num dos seus contatos com a imprensa, que a democracia que buscava para o Brasil não era aquela imaginada por estes ou por aqueles, mas a democracia que seu pai lhe ensinara. Agora, no dia do lançamento festivo do PDS (o novo 'maior partido do Ocidente'), o chefe da nação 
A Responsividade do leitor no gênero...

nos revela: 'Se eu não quisesse que a oposição falasse, ela não existiria'.

"Diante dessas manifestações parece não ser exagerado dizer que, ao menos no caso do Brasil, o presidente Figueiredo concebe a democracia como a organização política na qual todo o poder emana do chefe e sobre o povo é exercida. Com efeito, se ele pode fazer a democracia ou acabar com ela, extinguindo a oposição, é porque reconhece que nenhum controle político é exercido pelo povo dentro do regime em que nos encontramos.

"Penso que não seria impertinência pedir ao chefe da Nação que numa próxima oportunidade, gastasse algum tempo esclarecendo ao povo o que realmente entende por democracia" ${ }^{\circ}$.

Sr. Euclides Rossinholl (Ourinhos, SP) (FSP, 06/02/1980)

Co-gestão

"Ainda existe muita gente grande que acredita em Papai Noel. Pelo menos o governo acredita.

"Em quinze anos de regime autoritário, o trabalhador brasileiro foi cada vez mais explorado, sem que pudesse protestar contra isso. Pois bem. Agora que estamos com uma prometida eleição direta bem próxima, o Partido Democrático Social apresenta em seu programa a co-gestão para os trabalhadores.

"Para quem tem memória curta, convém lembrar que o atual PDS não é nada mais, nada menos que a antiga Arena com alguns adesistas a mais. E como ressaltou o senador Paulo Brossard, e para desespero dos pedessedistas, o general Ernesto Geisel disse que apenas o nome do partido mudara e nada mais.

"Os arenistas tiveram tempo de sobra para fazer e desfazer nesses passados quinze anos, mas só agora apresentam um programa voltado para o trabalhador. Um tanto estranho. E o pior de tudo isso é que muita gente ainda cai no conto do vigário".

Sr. Manoel Carlos Batista da Mata (Capital, SP)

(FSP, 09/02/1980)

${ }^{6}$ Para efeitos de análise, foram mantidas as aspas duplas, de acordo com o original publicado. 


\section{$2^{\text {o }}$ conjunto temático: Costumes: uso do topless, "corne- tões" nos estádios, filas.}

Saudável prática (1)

"Uma senhora de Brasília dirigiu-se a esse prestigioso matutino

- queixando-se - pelo visto- do fato de não ter ainda a 'Folha' divulgado e incentivado o tal topless.

"Não sou professor, nem pedagogo como a ilustre dama, mas louvo quem dá bons ensinamentos. Daí o meu espanto em ver alguém tentando estimular a prática que se me parece autêntica falta de pudor.

$(\ldots)$

Chega de permissividade de um lado e passividade de outro. Afinal de conta temos leis, forças espirituais, instituições respeitáveis que sabem o que é bom e o que não presta para o nosso caro Brasil $(\ldots)$

Sr. Evandro Campos (Taubaté)

(FSP, 03/02/1980)

Seios à mostra

"Há poucos dias li com muito interesse na 'Palavra do Leitor' uma carta sobre 'Topless- saudável prática', escrita por ema senhora, professora em Brasília. Aprovei completamente a posição e os conceitos dessa dama. Na edição de domingo, 03, tomei conhecimento com surpresa e indignação de três cartas sobre o mesmo tema, mas completamente contrárias à nova prática. Naturalmente os autores das cartas têm o direito de não concordar com o 'toples', mas, pelo menos que não o façam com argumentos tão pobres e tão convencionais. O pudor é uma atitude e uma posição moral, e não se mede em centímetros quadrados de pele coberta $(\ldots)$

Sra. Maria Elena Werner (FSP, 07/02/1980)

Em relação ao primeiro conjunto, vale observar o quadro axiológico forjado por tons de descrença, dúvida, no tocante à ascensão do general João Batista Figueiredo como presidente da república. Na primeira missiva, por exemplo, o autor tece seus comentários a partir de citações do próprio presidente, comparando-as. É a partir desse jogo comparativo que visa explicitar o que de acordo com seu ponto de vista revela-se aparentemente incoerente, considerando-se o próprio sentido da palavra "democracia" (governo do povo). 
Logo no início, o leitor já evidencia seu projeto discursivo: avaliar três "ocasiões" em que Figueiredo expõe sua "peculiar concepção" de democracia. A primeira citação, delimitada por aspas ('fazer deste País uma democracia'), arregimenta uma bivocalidade em que se fazem presentes duas vozes: 1) a do presidente ao afirmar suas intenções e 2) a do próprio autor que contesta tal afirmação. Tal contestação se delineia claramente se articulada à inserção das duas outras referências discursivas atribuídas ao general: a primeira, em forma de discurso indireto, aparece antecedida por um verbo dicendi, mobilizado pelo autor e que revela o teor avaliativo/ideológico de sua proposição: " $S$. Exa. nos advertiu num dos seus contatos com a imprensa...". Ora, o verbo "advertir", segundo o dicionário Caldas Aulete comporta dois significados: 1) fazer advertência, repreender; 2) avisar, prevenir. O contexto situacional circunscrito no processo de interação verbal aliado ao horizonte sócio-político amplo sinaliza a constituição de um sentido que mescla esses dois significados, a ponto de conferir ao discurso do presidente recém empossado o caráter de "grande pai" que se vê legitimado a admoestar seus "filhos" (representado na superfície linguística pelo pronome oblíquo "nos"), em uma relação nada equilibrada em termos de poder. A própria citação indireta (destacada pelo autor da carta) revela o sentido atribuído pelo general ao termo "democracia": aquela que "seu pai the ensinara". O papel social desempenhado por aquele que profere tal afirmação constitui-se foco de atenção por parte do leitor, de forma a revelar a contraposição ideológica entre o sentido da palavra "democracia" e o revestimento axiológico assumido pelo locutor que atribui ao mesmo termo o traço impositivo de seus próprios valores familiares, em uma única via possível de concepção de governo.

A terceira citação colocada em cena pelo autor de forma direta, entre aspas - 'Se eu não quisesse que a oposição falasse, ela não existiria'- ratifica a imagem de "grande chefe" detentor do poder de legitimar quem deve ou não falar. A "fala" é posta como sinônimo de existência. Aquele que porta o "direito" de se expressar é porque congrega o respaldo do poder político institucionalizado. Para finalizar a missiva, o leitor, ao estabelecer laços comparativos entre tais citações, modaliza seu próprio discurso: "Penso que não seria impertinência pedir ao chefe da Nação que numa próxima oportunidade, gastasse algum tempo esclarecendo ao povo o que realmente entende por democracia". Importante ressaltar que o gênero "carta do leitor" configura-se pela presença de múltiplos interlocutores, diferentemente de uma carta pessoal. Desse modo, o enunciado concreto entabula diálogo igualmente com outros leitores da FSP. Observamos que a carta arregimenta-se como instrumento público de contestação, uma vez que o foco temático abordado - o sentido valorativo de democracia constitui-se conteúdo objetal que permeia as relações públicas na inter-relação entre as instituições e os modos de existência do cidadão comum. 
Já a segunda carta do primeiro conjunto temático explicita mais fortemente o teor de descrença em relação à mudança de partido pelo governo. E isso se evidencia, por exemplo, na proposição de que "o governo acredita em Papai Noel", em uma referência à ideia de co-gestão de governo com os trabalhadores. O autor levanta a figura do "trabalhador", congregando a noção de classe social, de forma que seu discurso se constitui como uma espécie de mediador desse segmento. E é nessa condição que lembra os demais leitores acerca da confluência ideológica entre os partidos Arena e PDS: o primeiro, símbolo do autoritarismo militar, o segundo, "disfarce" do mesmo autoritarismo. Para confirmar sua perspectiva avaliativa, insere em sua fala um discurso sobre discurso: a citação do senador Paulo Brossard sobre a fala do general Geisel: "... o nome do partido mudara e nada mais". A escolha dos locutores e das citações legitima o tom axiológico do autor da carta que a finaliza equiparando a proposta a um "conto do vigário", expressão de caráter popular que sinaliza a ideia de "grossa mentira", de forma a reunir outros discursos que circulem na mesma esfera popular e que estejam afinados ideologicamente com esse leitor.

Compreende-se, destarte, que os discursos que emergem das autorias das cartas desse primeiro conjunto temático constituem-se representativas das vozes sociais que problematizam/contestam/refratam os discursos representativos do poder político então instituído. A despeito da vigência legal do regime de exceção, a publicação de tais missivas revela um posicionamento ideológico assumido discursivamente pelo enunciador Folha de S. Paulo: constituir-se porta-voz de múltiplas vozes sociais.

Já a recorrência de cartas do segundo conjunto temático evidencia a presença de discursos direcionados a questões comportamentais. O uso de topless, por exemplo, parece ter sido o foco de maiores divergências entre os próprios leitores da coluna A Palavra do Leitor. Observamos que as duas cartas selecionadas acima entabulam relações dialógicas de desacordo ( $1^{\underline{O}}$ carta) e acordo ( $2^{\underline{O}}$ carta) em relação à outra missiva publicada por uma leitora definida como professora e pedagoga que classifica o uso de topless como "saudável prática". Daí o título do enunciado seguido do número 1 entre parênteses (pois havia outras cartas refratando a fala da autora que se posicionava em defesa de tal uso). O que se revela, por um lado, é a presença de discursos conservadores, que defendem a existência de "instituições respeitáveis" e que mudanças comportamentais como a apontada configuram-se práticas "permissivas"; por outro, discursos que se contrapõem a esses de modo a articular a ideia de "pudor" não tão somente a valores da esfera da sensualidade, mas da moralidade. Constituem-se, portanto, discursos questionadores da ordem cultural estabelecida, o que fica evidente quando a autora da carta da FSP de 07/02/1980 considera o que não pode se constituir instrumento para medir o pudor: "os centímetros quadrados de pele coberta". 
Consideraremos em nossa pesquisa apenas os discursos refratados. A totalidade dos discursos apresentados apenas deve ser evidenciada com o propósito de situá-los em uma arquitetônica do próprio jornal. Essa se apresenta como o propósito/projeto de se constituir um espaço de manifestações críticas do leitor - daí o predomínio de discursos refratados. Contudo, é importante salientar que se observarmos o contexto sócio-econômico caracterizado pela manutenção da renda familiar graças à entrada de mais membros das famílias no mercado de trabalho em função do arrocho salarial (CARVALHO, 2008), é possível supor que tais críticas/discursos reflitam posicionamentos de grupos sociais eventualmente de um poder aquisitivo médio a superior, e de um nível de escolarização ao menos secundário uma vez que cerca de $30 \%$ da população acima de 15 anos ainda se apresentava analfabeta, aproximadamente 22 milhões de pessoas (BRANT et al, 2000).

Antes de focalizarmos as cartas da revista Veja publicadas na primeira quinzena de fevereiro de 1980, convém ainda pontuar que as correspondências contendo discursos refletidos de teor elogioso igualmente corroboram o direcionamento ideológico da arquitetônica do veículo que se apresenta como uma espécie de instrumento para fazer valer os direitos do cidadão em um país cuja noção de "direito" historicamente se viu, até certo ponto, esvaziada.

\subsection{AS "CARTAS" DA REVISTA VEJA}

Criada no auge da ditadura militar (1968), a revista Veja, produzida pelo grupo Abril, configura-se como um dos veículos de comunicação impresso mais lido no país com tiragem semanal aproximada de 1,2 milhão (SOUZA, 2003). Desde então, se apresenta como referência para outros segmentos da imprensa jornalística no país e até internacionalmente. Dessa forma, perguntamos: quais os discursos que emergem do gênero "carta do leitor" desse referido periódico? Há discursos refratados? Polemizam com quais outros discursos?

Se, em 1980, a coluna "A Palavra do leitor", da FSP, circulava ao lado direito da seção "Tendências e Debates" em que são publicados artigos assinados por especialistas, em Veja, no mesmo período, o espaço reservado ao gênero "carta do leitor" era denominado apenas "Cartas". Apresentava-se em duas colunas à esquerda (edição de 06/02/1980) ou à direita $(13 / 02 / 1980$ ) de um anúncio publicitário. Ao que parece, tal movimento já se constitui um indicativo de direcionamento ideológico: enquanto o primeiro aproxima a fala do leitor a dos demais interlocutores que compõem a edição jornalística, o segundo isola essa fala, do ponto de vista da organização espacial, fato que sinaliza um não comprometimento com os pontos de vista dos autores das 
cartas. O próprio nome da seção demonstra esse indicativo, na medida em que Veja não explicita a palavra "leitores".

Comparando as categorias discursivas identificadas a partir da leitura das cartas dos leitores da FSP com as de Veja (edições de 06/02/1980 e de 13/03/1980), obtivemos o seguinte quadro:

\section{I- Discursos refratados}

\section{I.I Interface entre a ideologia do cotidiano e esferas instituídas.}

- Polêmicas contra discursos das autoridades políticas instituídas (03).

- Polêmicas contra discursos advindos da esfera político-econômica (0).

- Polêmicas contra discursos oficiais oriundos da esfera da educação (0).

- Polêmicas contra discursos da esfera da religião(01).

- Polêmicas contra discursos da esfera midiática (01).

\section{Subtotal: 05}

I.II Interface entre discursos que circulam na esfera da ideologia do cotidiano: níveis superiores e inferiores

\section{Níveis superiores}

- Expressão axiológica de indignação: incitação ao engajamento político $(0)$.

- Expressão axiológica de indignação: cobrança institucional indevida de taxas e multas, preço alto, demora na restituição do imposto de renda, repasse reduzido de verbas $(0)$.

- Polêmica contra dirigentes esportivos e/ou imprensa (0).

- Polêmica contra discursos de técnicos agrícolas (0).

\section{Subtotal: 0}

\section{Niveis inferiores}

- Costumes/comportamento: uso do topless, "cornetões" nos estádios, filas (02).

- Violência urbana (0).

- Retirada dos nomes das listas telefônicas (0). 
A Responsividade do leitor no gênero...

Subtotal: 02

Total: 07

\section{Discursos refletidos}

II.I Cartas elogiosas

- Discurso elogioso do leitor ao senador Delfim Neto (13/02/1980), via análise de reportagem publicada em Veja (02).

- Discurso elogioso a artigo produzido por jornalista em edição anterior da Veja sobre obra no Iraque $(06 / 02 / 1980)(01)$.

- Discurso elogioso à reportagem de edição anterior de Veja sobre insegurança pública (13/02/1980) (01).

- Discurso elogioso à notícia publicada em edição de Veja, por ter "dado a certeza de que não mais haverá falta de insulina" (13/02/1980) (01).

- Discurso elogioso a Veja acerca da falta de sacerdotes no Brasil $(13 / 02 / 1980)(01)$.

- Discurso elogioso a Veja sobre difusão da fotografia no Brasil $(13 / 02 / 1980)(01)$.

\section{II.II Cartas propositivas ${ }^{7}$}

- Incentivo à pesca (0).

- Não suspensão de atividades de consórcio (0).

\section{II.III Cartas de solicitação}

- Solicita retificação de informação publicada incorretamente (00).

- Pedido ao governador de São Paulo para não instalar presídio em Ubatuba (00).

\footnotetext{
${ }^{7}$ As cartas propositivas delineiam-se pela apresentação de uma proposta de ação. No contexto da FSP, emergem duas delas: incentivo à atividade pesqueira e não suspensão de atividades de consórcio. Já as cartas de solicitação configuram-se por um pedido explícito: como pedido público de retificação ou solicitação ao governador para não instalação de presídio em região do litoral, como aparece na FSP.
} 


\section{II.IV Cartas de esclarecimento}

- Reitor da Universidade Federal do Paraná publica carta esclarecendo que não houve censura em solenidade de colação de grau ocorrida na referida universidade $(13 / 03 / 1980)(01)$.

- Editor da Global esclarece dúvidas quanto à possível "pirataria" em obra de Gregório Selser (06/02/1980)(01).

\section{Total: 09}

Das 16 cartas publicadas em duas edições do periódico na primeira quinzena de fevereiro, constatamos que ao menos $50 \%$ delas são constituídas por discursos refletidos (elogiosos) em relação a matérias publicadas pela revista Veja em edições anteriores, fato que sinaliza um projeto discursivo que enseja o propósito de evidenciar modos de repercussão do próprio trabalho. Nesse sentido, o periódico demonstra a intenção de destacar respostas positivas de seus leitores em relação às matérias publicadas em edições anteriores e sinalizar o aparente grau de aceitabilidade/credibilidade de seu trabalho jornalístico. Nesse contexto situacional, o que se apresenta perante o leitor não é o trabalho de edição das cartas, mas uma totalidade de publicações que reverberam positivamente a imagem do próprio enunciador, como atestam os seguintes enunciados:

\section{"O Brasil no deserto"}

Bela reportagem de VEJA $\mathrm{n}^{\mathrm{O}} 594$ sobre a obra que estamos empreendendo no Iraque. O artigo do jornalista Marcos de Sá Correa espelhou com fidelidade o esforço para exportar a tecnologia brasileira.

Murilo Valle Mendes,

Belo Horizonte, MG (06/02/1980)

\section{Insulina}

A notícia publicada em VEJA no 595 nos deu a certeza de que não passaremos novamente pelo período crítico, ocorrido recentemente, de falta de insulina. Esperávamos, porém, que também viesse a notícia de que baixaram os preços desse vital medicamente.

Ricardo Luiz Irineu Brito

Mineiros, GO

(Veja, 13/02/1980) 
A Responsividade do leitor no gênero...

Contudo, se focalizarmos os discursos refratados, verificaremos que parte deles igualmente se constitui via leitura de outros textos publicados pela própria revista. No enunciado a seguir, é possível observar que a inter-relação entre esferas (política instituída e ideologia do cotidiano) ocorre por meio de comentário do leitor acerca de declaração proferida pelo deputado Magalhães Pinto à Veja:

\section{Magalhães Pinto}

Pouco política a declaração do deputado Magalhães Pinto a VEJA, $\mathrm{n}^{\mathrm{O}}$ 593, afirmando que "os melhores médicos de Brasília são a Varig, VASP e Transbrasil". Sua afirmação é injusta, porque generalizada, é inábil, porque o indispõe com uma classe digna e competente. Maus profissionais há em todas as atividades, inclusive na política.

Donalva C. Marinho

Brasília, DF

(Veja, 06/02/1980)

Trata-se de uma polêmica aberta contra o discurso do então deputado Magalhães Pinto $^{8}$ ao avaliar a fala do deputado demarcada em seu próprio comentário por meio de uma citação direta. Observamos que a palavra "política" aparece bivocalizada uma vez que comporta ao menos dois sentidos: 1) pertinente às ações políticas, próprias do político; ou 2) respeitosa, amistosa. Nesse caso, a voz da leitora busca ser representativa de uma categoria social: dos médicos. O tom de polêmica velada se delineia, portanto, por meio dessa dupla vocalidade aliada ao subentendido posto ao final da missiva: "Maus profissionais há em todas as atividades, inclusive na política", em uma referência indireta não apenas à classe dos políticos, como também ao próprio autor da citação.

Abaixo, segue a página da edição de 06 de fevereiro de 1980:

Conclui-se, até o momento, que se na FSP há o predomínio de discursos refratados, uma responsividade do leitor caracterizada pelo predominio de polêmicas contra discursos das autoridades políticas instituídas ou embates discursivos em torno de temas que circulam no âmbito da ideologia do cotidiano, mais diretamente relacionados com costumes/comportamentos, de modo a

\footnotetext{
${ }^{8}$ José de Magalhães Pinto (1909-1996) foi o fundador da União Democrática Nacional (UDN). Após o golpe de 1964, fundou o Banco Nacional SA, com sede em Belo Horizonte. Foi duas vezes deputado por esse estado.
} 


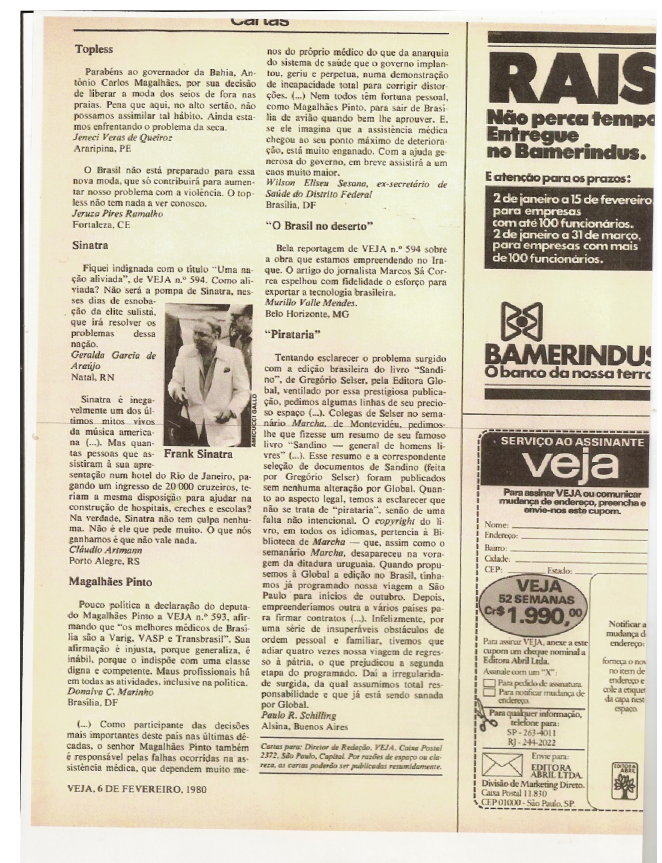

Figura 2: Página da edição de 06 de fevereiro de 1980

explicitar uma arquitetônica (projeto discursivo) caracterizada por se constituir em um espaço/instrumento de contestação de direitos; a revista Veja delineia uma arquitetônica forjada no sentido de se delimitar como uma voz de referência, de modo a selecionar cartas que ecoem expressões axiológicas favoráveis ao papel do referido veículo de comunicação.

Para finalizar o presente artigo, consideremos as cartas dos leitores publicadas pelo jornal $O$ Estado de S. Paulo no mesmo período:

\subsection{A RESPONSIVIDADE DO LEITOR DE OESP}

Ainda durante o Império, o jornal O Estado de S. Paulo (1875) emerge como veículo de comunicação patrocinado por republicanos abolicionistas ${ }^{9}$.

\footnotetext{
${ }^{9}$ Informações disponíveis no site: http://www.estadao.com.br/historico/resumo/conti1.htm. Acesso em 08 de maio de 2012.
} 
Na esteira de mudanças políticas e institucionais que beiravam o fim do século XIX, o jornal então denominado A província de São Paulo já sinalizava o propósito de se constituir parte do chamado "jornalismo impresso de referência". A esse propósito vale a pena investigar o direcionamento ideológico de tal veículo no período histórico mencionado ( $1^{\mathrm{O}}$ quinzena de 1980), que integra o primeiro ano de ascensão do presidente João Baptista Figueiredo, momento em que as severas amarras institucionais do regime se afrouxam em prol de uma incipiente democracia - com vistas a atribuir longevidade ao mesmo regime.

No tocante às análises das cartas dos leitores publicadas na primeira quinzena de fevereiro de 1980, é reveladora a recorrência de discursos refratados especialmente entre discursos advindos de segmentos representativos de instituições compreendidas como pertencentes à esfera da ideologia cotidiana em seus níveis superiores (representantes de cooperativas de cafeicultores, produtores de café, etc.) e discursos produzidos pelas autoridades institucionalizadas, bem como entre discursos de segmentos sociais predominantemente compreendidos como de profissionais liberais que polemizam contra discursos oficiais mantenedores do status quo: das 53 cartas consideradas, 30 explicitam refrações entre tais esferas. Dessas, concentrarnos-emos no estudo de dois tipos de enunciados concretos dispostos em função de dois focos temáticos, respectivamente: 1) contra discursos de autoridades políticas instituídas e 2) contra discursos oficiais sobre política internacional uma vez que se apresentam de forma mais recorrente.

Importante destacar que o primeiro tipo de enunciado concreto congrega temas que tangenciam questões de ordem política: simplificação de leis de zoneamento urbano; polêmica aberta contra a "incompetência" de administradores públicos; crítica a projetos de lei que criam novos pólos de desenvolvimento; análise de declaração de pronunciamento de militar sobre a ocupação na Amazônia; questionamento de programa do PDS que prevê expropriação de terras "improdutivas", etc. No segundo tipo de enunciado constatamos uma forte presença de vozes contrárias ao posicionamento do governo brasileiro de não aceitar a orientação do presidente norte-americano Carter para que empreendesse um boicote às Olimpíadas de Moscou. Esse fato mostra-se revelador de um perfil de leitor que se evidencia em sintonia com fatos internacionais que ganharam repercussão na época, como a invasão da então URSS no Afeganistão, mas também evidencia a preocupação quanto à possível expansão do comunismo, bem como a polarização política mundial entre dois grandes blocos: capitalistas, liderados pelos EUA e comunistas, capitaneados pela antiga URSS.

Já em relação às polêmicas entabuladas entre discursos que circulam na esfera da ideologia do cotidiano, ressaltaremos uma análise representativa das 
polêmicas emergentes em torno da possibilidade de se institucionalizar o aborto no Brasil, fato que revelará a emergência de discursos populares marcadamente conservadores e permeados por forte valor religioso. Os discursos refletidos, em número bastante reduzido (05) não serão avaliados, porém, importante ressaltar que tal dado se configura como antagônico ao apresentado nas análises das cartas de Veja, em que aparecem de forma mais proeminente. Em termos de recorrência temática e de emergência de discursos refletidos, tanto a FSP quanto OESP evidenciam reduzida presença em comparação com o número de cartas que arregimentam vários tons de polêmicas (entre aberta e velada). Tal fato constitui-se significativo em relação ao contexto sócio-político mais amplo caracterizado pelo incipiente processo de abertura democrática, bem como pelo projeto discursivo aparentemente assumido pelos dois jornais: apresentar-se como espaço de interlocução entre múltiplas vozes sociais.

Consideremos as seguintes categorias discursivas em comparação com as missivas publicadas no jornal FSP e revista Veja:

\section{I- Discursos refratados}

\section{I.I Interface entre a ideologia do cotidiano e esferas instituídas.}

- Polêmicas contra discursos das autoridades políticas instituídas (09).

- Polêmicas contra discursos advindos da esfera político-econômica (05).

- Polêmicas contra discursos oficiais oriundos da esfera da educação (01).

- Polêmicas contra discursos da esfera da religião (0).

- Polêmicas contra discursos da esfera midiática (02).

- Polêmicas contra discursos oficiais sobre saúde pública (06).

- Polêmicas contra discursos oficiais sobre política internacional (07)

\section{Subtotal: 30}

I.II Interface entre discursos que circulam na esfera da ideologia do cotidiano: níveis superiores e inferiores

Níveis superiores

- Expressão axiológica de indignação: incitação ao engajamento político (0).

- Expressão axiológica de indignação: preocupações ecológicas (03) 
A Responsividade do leitor no gênero...

Reader answerability in the genre...

- Expressão axiológica conservadora: contra ações de segmentos da esquerda que promovem greve e "anarquia" (01).

- Expressão axiológica de indignação: cobrança institucional indevida de taxas e multas, preço alto, demora na restituição do imposto de renda, repasse reduzido de verbas $(0)$.

- Expressão axiológica de indignação: corrupção em órgãos públicos (01).

- Expressão axiológica de indignação: morosidade no aumento do valor de aposentadorias (01).

- Polêmica contra dirigentes do BNH quanto aos critérios para concessão de casa própria (01).

- Polêmica contra segmentos oficiais responsáveis pelo sistema prisional brasileiro (01).

- Polêmica contra dirigentes esportivos e/ou imprensa (0).

- Polêmica contra discursos de técnicos agrícolas (0).

\section{Subtotal: 08}

\section{Níveis inferiores}

- Costumes/comportamento: aborto, transporte urbano, solidariedade, liberdade sexual, topless (10).

- Violência urbana (0).

- Retirada dos nomes das listas telefônicas (0).

\section{Subtotal: 10}

Total: 48

\section{Discursos refletidos}

\section{II.I Cartas elogiosas}

- Carta elogiosa ao OESP ao comentar a reportagem "Opções tarifárias", publicada em dezembro de 1979, em que se questionam os altos preços praticados no setor de venda de passagens aéreas (01).

\section{II.II Cartas propositivas}


- Incentivo à pesca $(0)$.

- Não suspensão de atividades de consórcio (0).

- Manutenção de porcentagem única de correção monetária aos salários (01)

- Programa de controle de natalidade (01)

- Todos os brasileiros alfabetizados tenham o direito de exercer a profissão de jornalista (01).

\section{II.III Cartas de solicitação}

- Solicita retificação de informação publicada incorretamente (01).

- Pedido ao governador de São Paulo para não instalar presídio em Ubatuba $(0)$.

\section{II.IV Cartas de esclarecimento}

\section{Nenhuma.}

\section{Total: 05}

A seguir, analisemos uma carta publicada em 09/02/1980 que exemplifica enunciados reveladores de polêmicas contra discursos advindos da esfera política:

\section{Os brasileiros convictos}

Sr. Redator

Muitas vezes a imprensa é acusada de distorcer declarações que lhe são feitas. Espero sinceramente que isto tenha acontecido em relação aos pronunciamentos do comandante do $1^{\mathrm{o}}$ Comando Aéreo Regional numa entrevista coletiva à imprensa ("Estado", 26/01). Pessoas e entidades que realmente conhecem as culturas indígenas brasileiras protestarão contra o teor de tais declarações. Entretanto, há outra coisa que me preocupa mais. O mencionado comandante é um brigadeiro, ou seja, uma alta patente que deve ter estudado por longos anos nas escolas militares. E sempre pensei que o currículo escolar de um oficial de carteira desse grande ênfase ao estudo da História. Por isso mesmo fiquei estarrecida com o desconhecimento de História nas declarações do brigadeiro que, como já disse, espero tenham sido deturpadas. Dizer "não 
A Responsividade do leitor no gênero...

queremos que a Amazônia seja um aglomeramento de países como a África" é ignorar tudo sobre os processos de formação dos Estados brasileiro e africano. Dizer que "a Amazônia só será nossa quando for povoada por brasileiros convictos e não por índios que não tem nacionalidade" é desconhecer que a brasilidade da Amazônia não se encontra ameaçada por meia dúzia de tribos que ali vivem há milênios, a Amazônia já é nossa, a não ser que a percamos, não para os índios, mas para os grupos estrangeiros e também de "brasileiros convictos" a quem não importa destruir seu equilíbrio ecológico desde que possam engrossar seus depósitos bancários e controlar politicamente áreas cada vez maiores dentro dela (...).

T Hartmann (capital)

(OESP, 09/02,1980)

Antes de analisarmos elementos constitutivos desse enunciado, importante observar que à guisa dos demais veículos (FSP e Veja), as cartas dos leitores de OESP aparecem sempre no início de cada edição (página 2), igualmente se posicionando como um espaço de interação que recupera outros discursos presentes em edições anteriores ou que circulam em outras esferas de atividade humana. Contudo, a coluna reservada a tais missivas, intitulada "Dos Leitores" aparece sempre ao lado direito de notícias que, em geral, priorizam a divulgação de temas de natureza política:

As três colunas reservadas a tais correspondências sinalizam um projeto discursivo do enunciador (OESP): demonstrar que atribui espaço relativamente grande à voz do leitor. De modo variável, aparecem de três a cinco cartas publicadas por edição e a primeira aparece com o título em fonte maior que os demais, o que faz supor que se trate de uma maneira de composição delineada com o propósito de destacar a primeira missiva em relação às subsequentes. Cada título congrega recorrentemente apenas uma carta, fato que parece tornar o leitor um "colaborador"/ "articulista" do jornal, representativo de segmentos sociais mais letrados.

Em relação ao enunciado escolhido, o foco gerador de refração discursiva encontra-se na tomada do discurso alheio como objeto de contestação (polêmica aberta). Contudo, a leitora, em seu projeto discursivo, relativiza, inicialmente, o embate axiológico que empreenderá ao longo de sua missiva ao levantar a hipótese de que a imprensa pode ter deturpado a palavra da autoridade um oficial militar de alta patente. Tal movimento discursivo sinaliza ainda certo cuidado com o direito de se manifestar abertamente contra discursos representativos do poder público oficial. Entretanto, ao mobilizar saberes que circulam em âmbito escolar como os modos de formação dos Estados brasileiro 


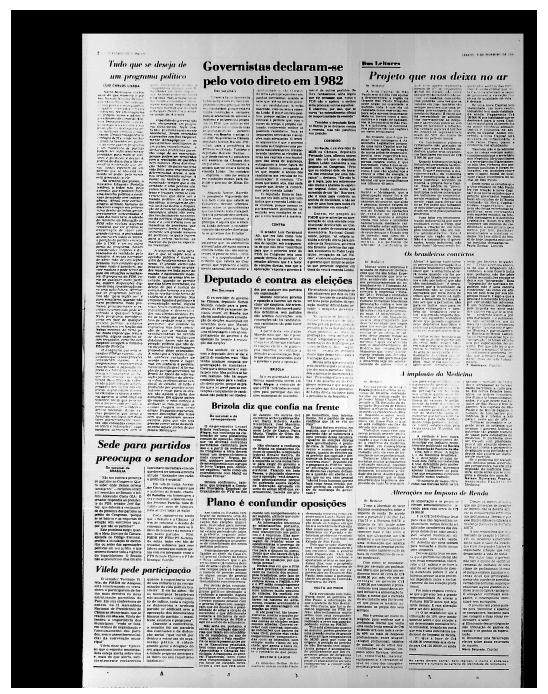

Figura 3: OESP, Edição de 09/02/1980

e africano, bem como a existência milenar de índios na região amazônica, a autora não apenas aponta o desconhecimento desses fatos por parte do militar, como também problematiza sua própria formação e, consequentemente, confere um tom de ironia em relação à capacidade do oficial em solucionar problemas relacionados à ocupação da região Amazônica.

A polêmica aberta instaurada pela leitora reveste-se de um tom de polêmica velada no momento em que mobiliza a bivocalidade do termo "brasileiros convictos": para o oficial, explicita a ideia de "cidadãos brasileiros", dentre os quais não se encontram os índios; já a leitora ironicamente observa que a referida "convicção" encontra-se muito mais atrelada a interesses pessoais ("engrossar os depósitos bancários") do que em manter o equilíbrio ecológico da região. O enunciador que publica tal missiva (OESP), ao realçar tal sintagma nominal no título do enunciado evidencia não a possibilidade de distorção da palavra do oficial pela mídia, mas a refração discursiva empreendida pela leitora que só constitui sentido na inter-relação com o texto da carta como um todo. Em outros termos, se o leitor do jornal observar esse título de forma isolada não o compreenderá em sua dimensão polêmica.

Consideremos, nesse momento, um enunciado em que emergem refrações discursivas contra discursos oficiais sobre política internacional: 
A Responsividade do leitor no gênero...

\section{O Brasil nas Olimpíadas}

Sr. Redator,

Tive o desgosto de saber que o presidente da República autorizou a ida da delegação brasileira às Olimpíadas de Moscou, não atendendo, portanto, ao pedido do presidente Carter. O boicote às Olimpíadas é uma maneira que os países com mais visão encontraram para manifestarem-se contra a invasão soviética no Afeganistão, portanto, os países que enviarem suas delegações às Olimpíadas estarão apoiando a atitude soviética em relação ao Afeganistão. "Parabéns" ao nosso presidente por apoiar o expansionismo soviético.

Roque Carvalho de Melo $\mathrm{F}^{\mathrm{O}}$

Presidente Prudente

(OESP, 12/02/1980)

Considerando a situação imediata de interlocução compreendida na interrelação entre autor (leitor)/ interlocutor (demais leitores)/ sentido do objeto (abordagem temática), em um gênero discursivo de teor eminentemente público e não pessoal, a manifestação de "desgosto" do autor reveste-se de indignação frente a um acontecimento de caráter social: a ida da delegação brasileira às Olimpíadas de Moscou. O contexto social amplo se circunscreve no enunciado na medida em que tal manifestação axiológica se explicita na contraposição entre dois posicionamentos ideológicos díspares: de um lado a "recomendação" do presidente norte-americano, de outro, o "expansionismo soviético", de modo a revelar a bipolaridade política internacional em um mundo dominado pelo sentimento da guerra fria. Desse modo, o uso do verbo "autorizou" não apenas se apresenta como dicendi, de modo a revelar o próprio discurso citado do chefe do executivo, mas também o legitima em seu posto como aquele que congrega em si a capacidade de mandar.Ao que parece, o autor da missiva não contesta tal legitimidade, mas o posicionamento ideológico do presidente ao não se alinhar às diretrizes de comando do líder da nação capitalista.

Desse modo, o autor estabelece uma distinção entre países que "têm mais visão" e aqueles que têm "menos". A polêmica velada se instaura na medida em que o leitor, ao analisar o foco temático "ida da delegação brasileira às Olimpíadas", confere ao Brasil o atributo de "país com menos visão", o que revela por parte de seu projeto discursivo que assume o discurso capitalista como superior ao socialista. Trata-se não apenas de refratar o discurso do presidente João Baptista Figueiredo - o que se torna evidente na ironia mobilizada no termo "parabéns" com aspas -, mas também de polemizar contra o virtual processo de expansão soviética no mundo. 


\section{CONSIDERAÇÕES FINAIS}

As análises preliminares apontam a presença de discursos refratados, caracterizados pela instauração de polêmicas (aberta ou velada) e discursos refletidos (cartas elogiosas, propositivas e de solicitação). Esse estudo visa considerar apenas os primeiros em uma perspectiva que avalie traços do projeto discursivo (arquitetônica) de cada enunciador (FSP, OESP e Veja), bem como dos enunciadores leitores/autores das missivas que se apresentam como vozes que se constituem socialmente de modo a refletir e refratar valores historicamente construídos.

É preciso ressaltar que, apesar do presente estudo não se concentrar em uma via de análise quantitativa, ela não se abstém de dados objetivos. Desse modo, observamos, de início, que OESP arregimenta a maior porcentagem de discursos refratados - 90\% (48 de um total de 53), ao passo que FSP congrega $85 \%$ (51 de um total de 61) e a revista Veja apenas 40\% (07 de um total de 16). Nesse último veículo, as análises dos enunciados concretos sinalizam uma responsividade, em geral, favorável aos discursos empreendidos pelas autoridades políticas instituídas, bem como um discurso laudatório em relação ao trabalho jornalístico da própria revista.

Já da FSP, emerge uma responsividade que sinaliza a presença de um leitor que concebe o espaço de interlocução como um instrumento para fazer valer seus direitos ou como um local de interação caracterizado pela troca de opiniões entre leitores na tomada de temas que circulam na esfera da ideologia do cotidiano, como o uso de topless. É nesse sentido que aparecem cartas que cobram o governo estadual de São Paulo para a não construção de presídio em Ubatuba, cobram a restituição do imposto de renda, etc. Ao lado dessas cartas, aparecem outras que problematizam questões de ordem política como a própria noção de "democracia" e as opções partidárias vigentes. Importante ressaltar que se trará de uma responsividade construída discursivamente no contexto de produção do jornal FSP, uma vez que tais publicações constituem-se ações intencionais por parte do editor e forjadas pelo início da abertura política.

Em relação ao jornal OESP, é reveladora a presença de vozes representativas de classes sociais: o presidente da cooperativa de cafeicultores, o presidente dos próprios cafeicultores que expressam descontentamento quanto à política econômica que desvaloriza o produto e eleva cultos; o médico que representa sua classe em função das "iniquidades" identificadas no Inamps; etc. Configurase igualmente objeto de contestação a política internacional desenvolvida pelo governo do presidente João Baptista Figueiredo que não demonstra apoiar o boicote à URSS, em uma demonstração de que o leitor de OESP, em carta selecionada pela própria editoria do jornal, de maneira ampla, 
revela-se favorável ideologicamente a pressupostos capitalistas delineados pelo governo norte-americano e teme a expansão soviética. Por outro lado, instaura polêmicas contra discursos da esfera política instituída, de modo que as cartas configuram-se, no espaço de três colunas em que o leitor expõe sua opinião.

De modo geral, por meio dessas análises, podemos dizer que a responsividade do leitor de Veja encontra-se afinada com o discurso do poder político instituído. O leitor do jornal FSP configura-se, via de regra, o cidadão que mobiliza o espaço como meio de se fazer ouvir e ouvir seus direitos perante órgãos públicos, em um momento da vida política brasileira em que até mesmo o direito do voto era tolhido em prol da ascensão de autoridades biônicas, indicadas por padrinhos políticos e, desse modo, passavam a dever "favores". Já OESP revela-se, de modo geral, detentor de uma responsividade perfilada a interesses de segmentos sociais organizados, como classes de profissionais liberais, sindicatos, produtores rurais, o que indica a presença de discursos ideologicamente em sintonia com valores de natureza conservadora como: manutenção do capitalismo, repúdio ao aborto, religiosidade e moralidade em contraposição aos discursos de liberdade sexual em vigor na mídia televisiva.

\section{REFERÊNCIAS BIBLIOGRÁFICAS}

BAKHTIN, M. M. O problema do conteúdo, do material e da forma na criação literária. In: BAKHTIN, M. M. Questões de literatura e estética: a teoria do romance. Trad. Aurora Fornoni Bernardini et al. $5^{\underline{O}}$ ed. São Paulo: Hucitec, 2002 [1924], p. 13-70.

BAKHTIN, M. M. O discurso no romance. In:BAKHTIN, M.M. Questões de literatura e estética: a teoria do romance. Trad. Aurora Fornoni Bernardini et al. $5^{0}$ ed. São Paulo: Hucitec, 2002 [1934-35]), p. 71-163].

BAKHTIN, M. M. Os gêneros do discurso. In Estética da criação verbal. Trad. Paulo Bezerra. São Paulo : Martins Fontes, 2006[1952-53]. p. 261-306.

BAKHtin, M. M. Problemas da poética de Dostoievski. Trad. Paulo Bezerra. 4. ed. Rio de Janeiro: Forense Universitária, 2008[1963].

BAKHTIN, M. M. Para uma filosofia do ato responsável. Trad.Valdemir Miotello; Carlos Alberto Faraco. São Carlos: Pedro\&João Editores, 2010[192024].

BAKHTIN, M. M. ; VOLOCHÍNOV, V. N. Marxismo e filosofia da linguagem. Trad. Michel lahud ; Yara Frateschi Vieira. 11. ed. São Paulo: Hucitec, 2004 [1929].

BRANT, L.L.N.A.O et al Um olhar sobre os indicadores de analfabetismo no Brasil. R.bras. Est. pedag., Brasília, v. 81, n.199, p.511-524, set./dez. 2000. 
CARVAlHO, J. M. de Cidadania no Brasil: o longo caminho. Rio de Janeiro: Civilização Brasileira, 2008.

CHAPARRO, M.C. C Carta. In: MELO,J.M. Gêneros jornalísticos na Folha de S. Paulo. São Paulo: FTD, 1987, p. 63 -74.

CORRÊA, Z. T. B. O gênero carta do leitor: análise de exemplares publicados no jornal Folha de S. Paulo. 2008, 175 p. Dissertação (mestrado em Ciências da Linguagem), Universidade do Sul de Santa Catarina, Tubarão, Santa Catarina.

SOUZA, V. A. A defesa incondicional do mercado em Veja: por que a revista age como age. 2003, 157 p., Dissertação (mestrado em Ciências Sociais) Pontifícia Universidade Católica de São Paulo, São Paulo. Disponível em: www.direitoacomunicacao.org.br/index2.php?option...

MAIngueneaU, D. Análise de textos de comunicação. Trad. Cecília P. de Souza-e-Silva; Décio Rocha. São Paulo: Cortez, 2002.

MEDVIÉDEV, P. N. O método formal nos estudos literários: introdução crítica a uma poética sociológica. Trad. Sheila Vieira e Camargo Grillo e Ekaterina Vólkova Américo. São Paulo, 2012.

VELOSO, S. R.A. Polêmicas discursivas na perspectiva bakhtiniana: embates entre vozes de cientistas e outros vozes na arena do Roda Viva. 2011, 272 p., Tese (doutorado em Letras) Faculdade de Filosofia, Letras e Ciências Humanas, Universidade de São Paulo, São Paulo. Disponível em : http://www.teses.usp.br/teses/disponiveis/8/8142/tde-15052012-140555/

VOLOCHíNOV, V. N. Le discours dans la vie et le discours dans la poésie: contribution à une poétique sociologique In TODOROV, T. Mikhaïl Bakhtine: le principe dialogique. Paris: Seuil, 1981[1926]. p. 181 -214.

VOLOCHíNOV, V. N. La structure de l'énoncé. In TODOROV, T. Mikhaïl Bakhtine: le principe dialogique. Paris: Seuil, 1981[1930]. p. 287-316.

Recebido em: 11/10/2012

Aceito em: 20/05/2013 